SHORT COMMUNICATION

\title{
Influence of Pregnancy, Parity and Stage of Lactation on Milk Yield and Composition in Crossbred Dairy Cattle
}

\author{
Lasna Sahib*, Pramod S., Bibin Becha B., Anu P Joseph and Thirupathy Venkatachalapathy R. \\ Livestock Research Station, Thiruvazhamkunnu, Palakkad, Kerala, INDIA \\ *Corresponding author: L Sahib; E-mail: lasna@kvasu.ac.in
}

Received: 25 Oct., 2019

Revised: 02 Dec., 2019

Accepted: 06 Dec., 2019

\begin{abstract}
The present study was conducted to explore the effect of pregnancy, parity and stage of lactation on milk yield and milk composition in crossbred cattle maintained at Livestock Research Station, Thiruvazahmkunnu, Palakkad, under Kerala Veterinary and Animal Sciences University. The farm is located at latitude, longitude and altitude of $11^{\circ} 21^{\prime}$ N , 76 $21^{\prime}$ 'E and 60$70 \mathrm{~m}$ above sea level and having a mean annual rainfall of 2,570 mm. Milk samples from 44 crossbred cows in different parity, stage of pregnancy and lactation were collected for seven consecutive days and composition was analyzed using Ekomilk Ultra pro milk analyzer (Milkana KAM 98-2A). The overall mean milk yield, fat, SNF, protein and lactose were $7.9 \mathrm{~kg}, 3.6 \%, 8.1 \%$, $3.2 \%$ and $4.2 \%$, respectively. Pregnant cows had significantly $(\mathrm{p}<0.05)$ lower milk yield $(6.06 v s 8.30 \mathrm{~kg})$ and significantly $(\mathrm{p}<0.05)$ higher lactose $(4.35 v s 4.23 \%)$ and SNF per cent $(8.28 v s$ 8.01\%) when compared to non-pregnant cows. Order of parity didn't have any influence on milk yield nor on the milk constituents. The mean milk yields during the three stages of lactation ( $<100$ days, 100-200 days and $>200$ days) were $9.23,7.57$ and $6.52 \mathrm{~kg} /$ day, respectively, with peak yield being observed during the first stage of lactation $(<100$ days). The stage of lactation had significant effect $(p<0.05)$ on milk yield and fat per cent whereas the other components were not influenced by the stage of lactation.
\end{abstract}

Keywords: Pregnancy, parity, lactation stage, milk yield, milk composition

The composition of milk is not only a concern for the milk producers but is equally significant to the processors and consumers. Many genetic and non-genetic factors have got a great impact on the composition of milk. Changes in the composition of milk may have a drastic bearing on the economy of a dairy farm due to pricing of milk on component basis. Hence having knowledge of the influence of non-genetic factors like lactation stage, pregnancy and parity on milk yield and composition, would aid in planning, so as to overcome the radical fluctuations in the returns of the producer. Hence the present work was carried out to study the effects of non-genetic factors like lactation stage, parity and pregnancy on milk yield and milk composition under the humid tropical climate of Kerala.

The study was conducted at Livestock Research Station, Thiruvazahmkunnu, Palakkad district, Kerala, under
Kerala Veterinary and Animal Sciences University. This place is located at latitude, longitude and altitude of $11^{\circ} 21^{\prime}$ $\mathrm{N}, 76^{\circ} 21^{\prime} \mathrm{E}$ and $60-70 \mathrm{~m}$ above sea level, respectively. It experiences a warm humid climate with a mean annual rainfall of $2,570 \mathrm{~mm}$, most of which is received during the south west monsoon season (June-August) (Anoop et al., 2011). Maximum air temperature ranged from $24.49^{\circ} \mathrm{C}$ (December) to $42.85{ }^{\circ} \mathrm{C}$ (March), while minimum air temperature ranged from $13.43{ }^{\circ} \mathrm{C}$ (January) to $27.02{ }^{\circ} \mathrm{C}$ (April). Relative humidity ranged from $9.11 \%$ to $100 \%$ (mean values from November 2014 to April 2018 obtained from Campbell Scientific, CR 800 data logger maintained in the campus).

The study was carried out in 44 crossbred lactating cows

How to cite this article: Sahib, L., Pramod, S., Bibin, B.B., Joseph, A.P. and Venkatachalapathy, T.R. (2019). Influence of pregnancy, parity and stage of lactation on milk yield and composition in crossbred dairy cattle J. Anim. Res., 9(6): 945-947. 
reared under intensive system during the month of July 2018. The cows were provided with type I cattle feed and green fodder (Guinea grass and Hybrid Napier), water was provided ad libitum and uniform managemental conditions were followed. Milk samples (morning) from the animals that were in different parity, pregnancy and stage of lactation were collected for seven consecutive days, analyzed for fat, SNF, protein and lactose using Ekomilk Ultra pro milk analyzer (Milkana KAM 98-2A) and average values per animal were taken for statistical analysis. Daily milk yield was also recorded for seven consecutive days and average values were used for statistical analysis. SPSS Version 20 software was used for analysis of data and Tukey test was used for comparing the means.

The milk yield and major milk constituents during different stages of lactation, pregnancy and parity are presented in table 1 . The average milk yield $(\mathrm{kg})$, fat, SNF, protein and lactose percent irrespective of parity, pregnancy and stage of lactation were 7.9, 3.6, 8.1, 3.2 and 4.2, respectively.

Milk yield was significantly $(\mathrm{p}<0.05)$ lower whereas SNF and lactose percent were significantly $(\mathrm{p}<0.05)$ higher in pregnant animals when compared to non-pregnant animals. A decline in milk yield with pregnancy has also been reported by Akers (2002) and Pratap et al. (2014).
This may be due to hormonal changes causing regression of the mammary gland and nutrient requirements of the foetus, reducing available nutrients for milk production (Bell et al., 1995). A numeric increase in protein percent in pregnant animals could be observed which may be due the general increments in anabolism of major nutrients during pregnancy. The increase in protein and lactose percent would have resulted in significant increase in SNF in pregnant animals. Similar results were reported by Gurmessa and Melaku (2012) and Pratap et al. (2014) who observed a significant increase in SNF, protein and lactose contents of the milk during pregnancy.

Milk constituents and milk yield were not affected by the order of parity. Similar results were reported by Gurmessa and Melaku (2012) and Pratap et al. (2014) who observed that milk yield and major milk components (fat, SNF, protein and lactose) were not influenced by parity. This was in contrast to the results of Yoon et al. (2004) who observed that milk yield, milk fat and protein varied significantly with parity.

The mean milk yield during the three stages of lactation $(9.23,7.57$ and $6.52 \mathrm{~kg} /$ day) was higher than $6.81,7.17$ and $5.48 \mathrm{~L} / \mathrm{d}$ as reported by Pratap et al. (2014) in crossbred Holstein-Friesian cows. The stage of lactation had significant effect $(p<0.05)$ on milk yield and fat percent

Table 1: Effect of stage of lactation, pregnancy and parity on milk yield and major milk constituents

\begin{tabular}{|c|c|c|c|c|c|c|}
\hline & $\mathbf{n}$ & Milk yield (kg) & Fat $\%$ & SNF \% & Protein \% & Lactose $\%$ \\
\hline \multicolumn{7}{|l|}{ Stage of lactation } \\
\hline$<100$ days & 18 & $9.23^{b} \pm 0.77$ & $3.37^{\mathrm{a}} \pm 0.14$ & $8.00 \pm 0.08$ & $3.14 \pm 0.03$ & $4.23 \pm 0.04$ \\
\hline 100 to 200 days & 11 & $7.57^{\mathrm{ab}} \pm 0.58$ & $3.74^{\mathrm{ab}} \pm 0.14$ & $8.00 \pm 0.08$ & $3.16 \pm 0.04$ & $4.21 \pm 0.05$ \\
\hline$>200$ days & 15 & $6.52^{\mathrm{a}} \pm 0.58$ & $3.89^{\mathrm{b}} \pm 0.14$ & $8.17 \pm 0.07$ & $3.23 \pm 0.02$ & $4.30 \pm 0.04$ \\
\hline \multicolumn{7}{|c|}{ Pregnancy (above 3 months) } \\
\hline Pregnant & 8 & $6.06^{\mathrm{a}} \pm 0.82$ & $3.98 \pm 0.15$ & $8.28^{b} \pm 0.10$ & $3.25 \pm 0.03$ & $4.35^{\mathrm{b}} \pm 0.06$ \\
\hline Non-pregnant & 36 & $8.30^{\mathrm{b}} \pm 0.47$ & $3.56 \pm 0.10$ & $8.01^{\mathrm{a}} \pm 0.05$ & $3.16 \pm 0.02$ & $4.23^{\mathrm{a}} \pm 0.02$ \\
\hline \multicolumn{7}{|l|}{ Parity } \\
\hline 1 & 13 & $8.45 \pm 0.73$ & $3.58 \pm 0.19$ & $8.11 \pm 0.07$ & $3.17 \pm 0.03$ & $4.28 \pm 0.04$ \\
\hline 2 & 17 & $7.34 \pm 0.73$ & $3.71 \pm 0.14$ & $8.01 \pm 0.08$ & $3.14 \pm 0.03$ & $4.24 \pm 0.04$ \\
\hline 3 & 9 & $7.27 \pm 0.81$ & $3.87 \pm 0.15$ & $8.18 \pm 0.08$ & $3.22 \pm 0.03$ & $4.28 \pm 0.04$ \\
\hline
\end{tabular}

Mean \pm SE of $n$ observations

Means bearing at least one common superscript within a column do not differ significantly $(\mathrm{P}<0.05)$. 
whereas the other components were not influenced by the stage of lactation. Milk yield decreased linearly as days in milk increased while milk fat percent increased linearly. Similar results were reported by Yoon et al. (2004). This was in contrary to the results of Gurmessa and Melaku (2012) who reported the occurrence of the peak milk yield at the mid lactation. The milk yield was significantly $(p<0.05)$ lower and fat percent was significantly higher in the lactation stage above 200 days when compared to lactation stage below 100 days. Similar results were reported by Gurmessa and Melaku (2012) and Shuiep et al. (2016). The increase in milk fat percent in late lactation may be due to reduced milk yield during this period as reported by Auldist et al. (1998). However Sudhakar et al. (2013) reported that milk constituents and milk yield were not influenced by the stage of lactation.

\section{CONCLUSION}

The present study indicated that pregnancy has got a significant effect on milk yield and milk composition with pregnant cows having lower milk yield and higher lactose and SNF per cent when compared to non-pregnant cows. The milk yield and milk composition was not affected by the order of parity. The stage of lactation had significant effect on milk yield and fat percent whereas the other components were not influenced by the stage of lactation.

\section{REFERENCES}

Akers, R.M. 2002. Major advances associated with hormone and growth factor regulation of mammary growth and lactation in dairy cows. J. Dairy Sci., 89(4): 1222-1234.
Anoop, E.V., Ajayghosh, V. and Pillai, H. 2011. Variation in wood anatomical properties of selected indigenous, multipurpose tree species grown in research trials at LRS Thiruvazhamkunnu, Palakkad, Kerala. J. Indian Acad. Wood. Sci., 8(2): 100-105.

Auldist, M.J., Walsh, B.J. and Thomson, N.A. 1998. Seasonal and locational influences on bovine milk composition in New Zealand. J. Dairy Res., 65: 401-411.

Bell, A.W., Slepetis, R. and Ehrhardt, R.A. 1995. Growth and accretion of energy and protein in the gravid uterus during late pregnancy in Holstein cows. J. Dairy Sci., 78(9): 19541961.

Gurmessa, J. and Melaku, A. 2012. Effect of lactation stage, pregnancy, parity and age on yield and major components of raw milk in bred cross Holstein Friesian cows. World J. Dairy Food Sci., 79(2): 146-149.

Pratap, A., Verma, D.K., Kumar, P. and Singh, A. 2014. Effect of pregnancy, lactation stage, parity and age on yield and components of raw milk in Holstein Friesian cows in organized dairy farm in Allahabad. IOSR J. Agri. Vet. Sci., 7(2): 112-115.

Shuiep, E.S., Eltaher, H.A. and El Zubeir, I.E.M. 2016. Effect of stage of lactation and order of parity on milk composition and daily milk yield among local and crossbred cows in south Darfur state, Sudan. J. Agric. Vet. Sci., 17(2): 86-98.

Sudhakar, K., Panneerselvam, S., Thiruvenkadan, A.K., Abraham, J. and Vinodkumar, G. 2013. Factors effecting milk composition of crossbred dairy cattle in southern India. Int. J. Food Agric. Vet. Sci., 3(1): 229-233.

Yoon, J.T., Lee J.H., Kim, C.K., Chung, Y.C. and Kim, C.H. 2004. Effects of milk production, season, parity and lactation period on variations of milk urea nitrogen concentration and milk components of Holstein Dairy Cows. Asian-Aust. J. Anim. Sci., 17(4): 479-484. 